\title{
Ekspresi Human Leukocyte Antigen-G (HLA-G) dan Heat-Shock Protein-70 (Hsp-70) pada Pertumbuhan Janin Terhambat
}

\author{
Sri Sulistyowati, Anak Agung Eka W. \\ Divisi Fetomaternal Bagian Obstetri dan Ginekologi Fakultas Kedokteran Universitas Sebelas Maret \\ Rumah Sakit Umum Daerah Dr. Moewardi Surakarta
}

\begin{abstract}
Abstrak
Pertumbuhan janin terhambat (PJT) merupakan salah satu penyebab utama tingginya morbiditas dan mortalitas perinatal. Maladaptasi imun berakibat gangguan invasi trofoblas dan remodeling arteri spiralis yang akan menyebabkan hipoksia pada jaringan plasenta. Penelitian ini bertujuan untuk menganalisis ekspresi human leukocyte antigen-G (HLA-G) dan heat-shock protein-7 (Hsp-70) pada trofoblas PJT dan hamil normal, dengan menggunakan metode observasional analitik dan pendekatan potong lintang. Penelitian dilakukan di Bagian Obstetri dan Ginekologi Rumah Sakit Umum Daerah Dr. Moewardi Surakarta, mulai bulan November-Desember 2011. Jumlah sampel 30, terdiri atas 15 sampel trofoblas pada PJT dan 15 sampel trofoblas pada kehamilan normal. Pada semua sampel dilakukan pemeriksaan ekspresi HLA-G dan Hsp-70 dengan imunohistokimia. Analisis data menggunakan uji-t. Ekspresi HLA-G rata-rata pada kelompok PJT sebesar 32,42 $\pm 8,90$, sedangkan ekspresi HLA-G rata-rata pada kelompok kehamilan normal 43,92 $\pm 14,91(\mathrm{p}=0,016)$. Ekspresi Hsp-70 pada kelompok PJT $2,4355+0,26647$ dan kelompok kehamilan normal 1,5920+0,17142 ( $p=0,008)$. Simpulan, pada PJT ekspresi HLA-G lebih rendah dan ekspresi Hsp-70 lebih tinggi dibandingkan dengan kehamilan normal. [MKB. 2014;46(1):22-7]
\end{abstract}

Kata kunci: HLA-G, Hsp-70, pertumbuhan janin terhambat

\section{Human Leukocyte Antigen-G (HLA-G) and Heat-Shock Protein-70 (Hsp-70) Expression on Intra Uterine Growth Retardation}

\begin{abstract}
Intra uterine growth retardation (IUGR) is one of the leading causes of higher morbidity and mortality in perinatal. Immune maladaptation affects trophoblast invasion and spiralis arteria remodeling that will cause placental tissue hypoxia. This research aimed to analyze human leukocyte antigen-G (HLA-G) and heat-shock protein-70 (Hsp70) expression on the IUGR trophoblast and normal pregnancy, by applying analytical observational method and cross sectional approach. This research was conducted at the Obstetric and Gynecology Department of Dr. Moewardi Hospital Surakarta from November to December 2011. The total samples were 30, divided into two groups. There were 15 samples trophoblast on IUGR and 15 samples trophoblast from normal pregnancy. All samples were tested for HLA-G and Hsp-70 using immunohistochemistry. The data were analyzed by using t-test. The mean of HLA-G expression on the IUGR groups was $32.42 \pm 8.90$ and on the normal pregnancy groups was $43.92 \pm 14.91(p=0.016)$. Heat-shock protein70 expression on the IUGR groups was $2.4355+0.26647$ and on the normal pregnancy groups was $1.5920+0.17142$ with $p=0.008$. In conclusion, in IUGR, the HLA-G expression is lower and the Hsp-70 expression is higher than in normal pregnancy. [MKB. 2014;46(1):22-7]
\end{abstract}

Key words: HLA-G, Hsp-70, intra uterine growth retardation

Korespondensi: Dr. Sri Sulistyowati, dr., Sp.OG(K), Divisi Fetomaternal Bagian Obstetri dan Ginekologi Fakultas Kedokteran Universitas Sebelas Maret/Rumah Sakit Umum Daerah Dr. Moewardi Surakarta, mobile 08122968215, e-mail elis_spog@ yahoo.co.id 


\section{Pendahuluan}

Pertumbuhan janin terhambat (PJT) merupakan keadaan yang menunjukkan berat badan janin di bawah 10 persentil untuk masa kehamilan atau $<2$ standar deviasi di bawah rata-rata masa kehamilan. Selain berat badan, beberapa penulis mendefinisikan PJT dengan lingkar perut $\leq 5$ persentil atau femur lenght (FL) atau abdominal circumference $(\mathrm{AC})>24 .^{\prime}$ Pertumbuhan janin terhambat sampai saat ini masih menjadi penyebab paling utama morbiditas dan mortalitas perinatal. Sekitar 2-10\% kehamilan berhubungan dengan PJT dan 20\% dari janin lahir mati mengalami PJT. Insidensi PJT di Indonesia sebesar 4,4\%, dan di Rumah Sakit Umum Daerah (RSUD) Dr. Moewardi Surakarta, kejadian PJT pada tahun 2008 sekitar $13 \%{ }^{2}$

Fetus adalah jaringan semialograf (membawa antigen ayah). Pada kehamilan normal fetus tidak ditolak oleh ibu, kemungkinan disebabkan oleh karena mekanisme toleransi respons ibu, baik lokal antara trofoblas dan sel imun ibu di desidua pada awal kehamilan maupun karena respons imun sistemik sel imun ibu dalam sirkulasi dengan sinsitiotrofoblas. ${ }^{3,4}$

Human leukocyte antigen-G (HLA-G) adalah produk lokus genetik mayor histocompatibility complex (MHC) yang terletak pada kromosom 6. Human leukocyte antigen- $G$ merupakan molekul MHC kelas Ib nonklasik, bersifat monomorfik dan memiliki kemampuan menghambat aktivitas natural killer (NK) cell serta large granular lymphocytes (LGLs) desidua, sehingga HLA-G berfungsi untuk dapat melindungi trofoblas dari pengaruh imun maternal atau serangan sitotoksik maternal. Ekspresi HLA-G yang cukup pada trofoblas diperlukan untuk memodulasi sekresi sitokin bertujuan menginduksi toleransi imun, mengontrol invasi trofoblas, dan berkontribusi dalam remodeling arteri spiralis untuk menunjang keberhasilan implantasi dan kehamilan. Jika HLA-G tidak diekspresikan ataupun menurun, trofoblas akan dihalangi untuk dapat menginvasi desidua. Pada waktu yang bersamaan, sel NK akan menghancurkan trofoblas yang HLA-Gnya kurang. Tanpa invasi trofoblas yang tepat, maka arteri maternal tidak akan dibentuk ulang sehingga aliran utero plasenta menurun dan terjadi hipoksia/iskemia plasenta yang menyebabkan PJT. $^{3}$

Heat-shock protein-70 mempunyai peranan yang krusial sebagai sitoprotektor intraselular dan molekul chaperon untuk mempertahankan kondisi sel-sel yang baik, dari serangan patogen. Heat-shock protein-70 akan membuat sintesis polipeptida pada folding baru (oleh karena stres). Ekspresi Hsp-70 yang mengalami peningkatan pada janin tumbuh lambat diduga karena respons dari stres multipel. ${ }^{5}$

Iskemia, hipoksia, dan peningkatan resistensi vaskular yang mengakibatkan kerusakan fungsi plasenta sebagian besar disebabkan oleh karena peningkatan stres oksidatif. Heat-shockprotein-70 merupakan marker stres oksidatif, pada trofoblas ekspresinya meningkat pada kasus PJT dan preeklamsi dibandingkan dengan trofoblas hamil normal. Stres oksidatif mempunyai peran yang penting dalam patogenesis PJT dan preeklamsi. ${ }^{6}$

Plasenta sangat berperan pada perkembangan janin selanjutnya. Penyakit vaskular pada plasenta mengakibatkan komplikasi kehamilan seperti PJT dan juga preeklamsi. Heat-shock protein-70 ditemukan meningkat pada kasus PJT. Stres oksidatif berhubungan dengan penyakit vaskular plasenta. Kondisi stres menyebabkan sel endotel melepaskan nitrid oxide (NO) yang akan memicu peningkatan Hsp-70. Kondisi ini merupakan proteksi sel jaringan dari kondisi hipoksia dan reperfusi iskemia. ${ }^{7}$ Penelitian ini bertujuan untuk menganalisis ekspresi HLA-G dan Hsp-70 pada PJT dan hamil normal.

\section{Metode}

Penelitian dilaksanakan di Bagian Obstetri dan Ginekologi RSUD Dr. Moewardi Surakarta mulai Bulan November-Desember 2011. Pemeriksaan ekspresi HLA-G dan Hsp-70 digunakan metode imunohistokimia di laboratorium PA (Patologi Anatomi) Fakultas Kedokteran (FK) Universitas Sebelas Maret Surakarta. Jenis penelitian adalah observasional analitik (eksplanatori) memakai rancang bangun potong lintang.

Penelitian dilakukan pada ibu hamil dengan PJT dan ibu hamil normal untuk menganalisis ekspresi protein HLA-G dan juga Hsp-70 pada trofoblasnya. Besar sampel untuk uji hipotesis ditentukan berdasarkan replikasi dari Murti. ${ }^{8}$ Berdasarkan rumus tersebut, besar sampel untuk tiap kelompok adalah 15 orang. Kriteria inklusi yaitu primigravida, usia $<35$ tahun, yangmemenuhi kriteria PJT dan hamil normal, tidak mengidap penyakit kronik (misal diabetes melitus, kelainan ginjal, kelainan jantung, hipertensi kronik, infeksi kronik, merokok, dan anemia). Kriteria eksklusi yaitu kehamilan kembar, kematian janin dalam rahim, ibu hamil dengan ketuban pecah dini, infeksi intrauterin, dan janin dengan kelainan kongenital. Kriteria drop out yaitu pasien yang tidak bersedia meneruskan penelitian dan pasien yang meninggal saat berlangsungnya penelitian. Sampel dibagi menjadi 2 (dua) kelompok yaitu kelompok kasus adalah kehamilan dengan PJT dan kelompok kontrol yaitu kehamilan normal. 
Pada kedua kelompok penelitian ini dilakukan pemeriksaan trofoblas yang merupakan bagian dari plasenta untuk menganalisis ekspresi protein HLA-G dan Hsp-70 dengan menggunakan metode imunohistokimia. Analisis hasil dilakukan uji-t dengan nilai kepercayaan $95 \%$.

\section{Hasil}

Berdasarkan riwayat kehamilan, sebagian besar kelompok PJT adalah multigravida, sedangkan pada kehamilan normal semuanya primigravida. Pemeriksaan antenatal paling banyak dikunjungi kedua kelompok sama, yaitu bidan dan rumah sakit. Frekuensi kunjungan antenatal sebagian besar 3-6 kali, baik pada kelompok PJT maupun kehamilan normal. Sebagian besar kelompok PJT bersalin dengan seksio sesaria, sedangkan pada kelompok kehamilan normal semua persalinan dengan per vaginam. Tingkat pendidikan subjek penelitian sama, baik pada kelompok PJT maupun kelompok kehamilan normal yaitu sebagian besar lulus sekolah menengah pertama. Pekerjaan ibu pada kedua kelompok sebagian besar adalah ibu rumah tangga (Tabel 1).

Pemeriksaan ekspresi HLA-G pada trofoblas yang merupakan bagian dari plasenta dilakukan menggunakan metode imunohistokimia dengan antibodi primer yaitu berupa mouse monoclonal antibody HLA-G (Bio Vendor, RD 194070100R). Molekul HLA-G terekspresi di trofoblas dengan berwarna merah pada sitoplasma oleh karena terjadi reaksi antigen antibodi molekul HLA-G dengan mouse monoklonal anti-HLA-G yang divisualisasikan dengan pewarnaan amino etil carbazole (AEC). Penelitian ini menggunakan mikroskop dengan pembesaran 400x.

Dari hasil pembacaan metode imunohistokimia diperoleh bahwa distribusi HLA-G rata-rata pada jaringan trofoblas kelompok PJT lebih rendah bila dibandingkan dengan kelompok kehamilan normal (Gambar 1).

Ekspresi human leukocyte antigen-G/HLA-G rata-rata pada jaringan trofoblas kelompok PJT $(32,42 \pm 8,90)$ lebih rendah dibandingkan dengan

Tabel 1 Karakteristik Subjek Penelitian

\begin{tabular}{|c|c|c|}
\hline Variabel & $\begin{array}{c}\text { PJT } \\
\mathrm{n}=15\end{array}$ & $\begin{array}{c}\text { Normal } \\
\mathrm{n}=15\end{array}$ \\
\hline \multicolumn{3}{|l|}{ Paritas } \\
\hline Primigravida & 5 & 15 \\
\hline Multigravida & 10 & 0 \\
\hline \multicolumn{3}{|l|}{ Tempat pemeriksaan antenatal } \\
\hline Bidan & 6 & 6 \\
\hline Puskesmas & 3 & 2 \\
\hline Rumah sakit & 6 & 5 \\
\hline Spesialis obstetri ginekologi & 0 & 2 \\
\hline \multicolumn{3}{|l|}{ Frekuensi pemeriksaan antenatal } \\
\hline $3-6 x$ & 11 & 8 \\
\hline$>6 \mathrm{x}$ & 4 & 7 \\
\hline \multicolumn{3}{|l|}{ Cara persalinan } \\
\hline Per vaginam & 3 & 15 \\
\hline Seksio sesaria & 12 & 0 \\
\hline \multicolumn{3}{|l|}{ Pendidikan ibu } \\
\hline Sekolah dasar & 3 & 2 \\
\hline Sekolah menengah pertama & 9 & 7 \\
\hline Sekolah menengah atas & 3 & 6 \\
\hline \multicolumn{3}{|l|}{ Pekerjaan ibu } \\
\hline Ibu rumah tangga & 9 & 8 \\
\hline Bekerja & 6 & 7 \\
\hline
\end{tabular}


Tabel 2 Distribusi Ekspresi HLA-G dan Hsp-70 Rata-rata pada Jaringan Trofoblas Kelompok PJT dan Kehamilan Normal

\begin{tabular}{lccc}
\hline \multicolumn{1}{c}{ Ekspresi Rata-rata } & PJT & Normal & p \\
\hline HLA-G \pm SD & $32,42 \pm 8,90$ & $43,92+14,91$ & 0,016 \\
Hsp-70 & $2,4355+0,26647$ & $1,5920+0,17142$ & 0,008 \\
\hline
\end{tabular}

kehamilan normal $(43,92 \pm 14,91)$, dengan uji-t didapatkan nilai $\mathrm{p}=0,016(\mathrm{p}<0,05$; Tabel 2). Data ini menjelaskan bahwa bila ekspresi HLA-G tidak mencukupi maka trofoblas akan dihambat untuk menginvasi arteri spiralis sehingga terjadi hipoksia plasenta yang akan menyebabkan PJT.

Pemeriksaan Hsp-70 pada trofoblas dilakukan menggunakan metode imunohistokimia dengan antibodi primer mouse monoclonal antibody Hsp70 (Assay Designs, EKS-715). Molekul Hsp-70 terekspresi di trofoblas dengan warna merah pada sitoplasma karena terjadi reaksi antigen antibodi antara molekul Hsp-70 dan mouse monoklonal anti-Hsp-70 yang telah divisualisasikan dengan pewarnaan amino etil carbazole/AEC. Penelitian mempergunakan mikroskop dengan pembesaran 400x.

Dari hasil pembacaan metode imunohistokimia didapatkan distribusi ekspresi Hsp-70 rata-rata pada jaringan kelompok trofoblas kehamilan PJT lebih tinggi dibandingkan dengan kehamilan normal (Gambar 2).

Data ekspresi Hsp-70 rata-rata pada jaringan trofoblas kelompok PJT $(2,4355 \pm 0,26647)$ lebih tinggi bila dibandingkan dengan ekspresi Hsp70 pada kehamilan normal $(1,5920 \pm 0,17142)$, dengan uji-t didapatkan nilai $\mathrm{p}=0,008(\mathrm{p}<0,05$; Tabel 2). Data ini dapat menjelaskan bahwa pada
PJT, ekspresi Hsp-70 yang tinggi terjadi karena respons stres akibat hipoksia plasenta.

\section{Pembahasan}

Pada kehamilan yang normal, ekspresi HLA-G yang cukup akan melindungi trofoblas terhadap serangan imun maternal sehingga trofoblas dapat melakukan invasinya pada desidua dengan baik. Sebaliknya, apabila ekspresi HLA-G itu rendah, maka trofoblas akan dicegah untuk menginvasi jaringan maternal dengan baik karena trofoblas dianggap sebagai antigen (non self), sehingga dihancurkan oleh sel inflamasi antara lain sel T dan sel NK yang dihasilkan dari reaksi antigen dan antibodi. Invasi trofoblas yang tidak baik akan menyebabkan hipoksia di jaringan plasenta yang akan menyebabkan komplikasi kehamilan seperti PJT, preeklamsi, dan abortus berulang. ${ }^{9,10}$

Ekpresi HLA-G pada plasenta ideopathic fetal growth restriction (IFGR) dan hubungannya dengan patogenesis telah diteliti oleh Fan dkk. ${ }^{11}$ dengan hasil penurunan yang signifikan ekspresi HLA-G pada IFGR dengan nilai $p=0,017$ dan berhubungan dengan lesi patologi pada plasenta. Human leukocyte antigen-G mungkin memegang peranan penting dalam patogenesis IFGR.

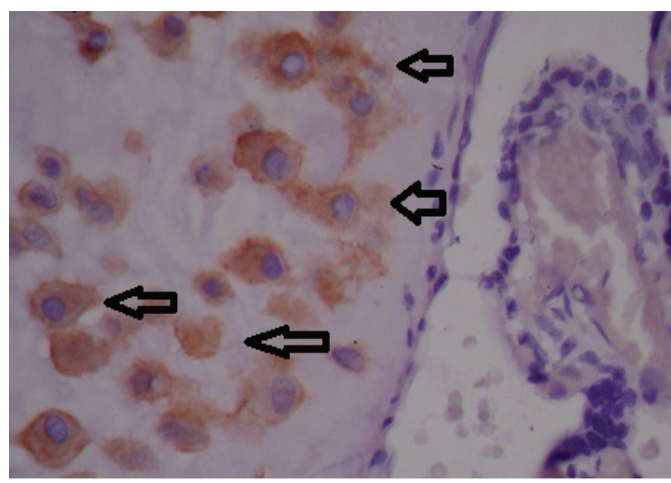

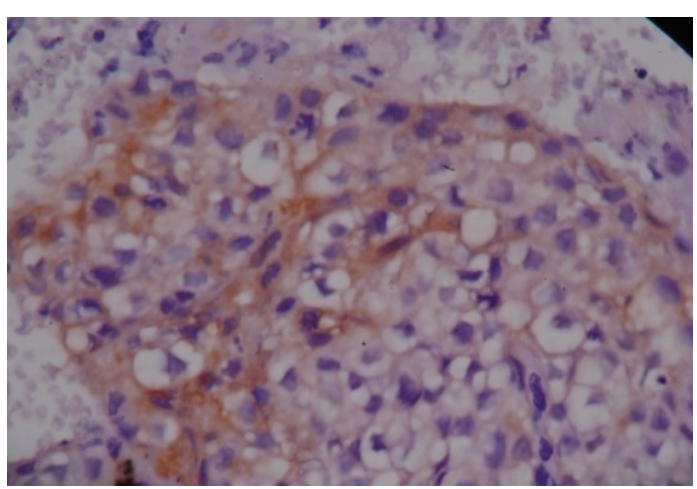

Gambar 1 Ekspresi HLA-G dengan Metode Imunohistokimia. Kiri: Ekspresi HLA-G pada kehamilan normal. Kanan: Ekspresi HLA-G pada PJT. Human leucocyte antigen-G positif bila tampak berwarna merah pada sitoplasma trofoblas dengan menggunakan substrat AEC 

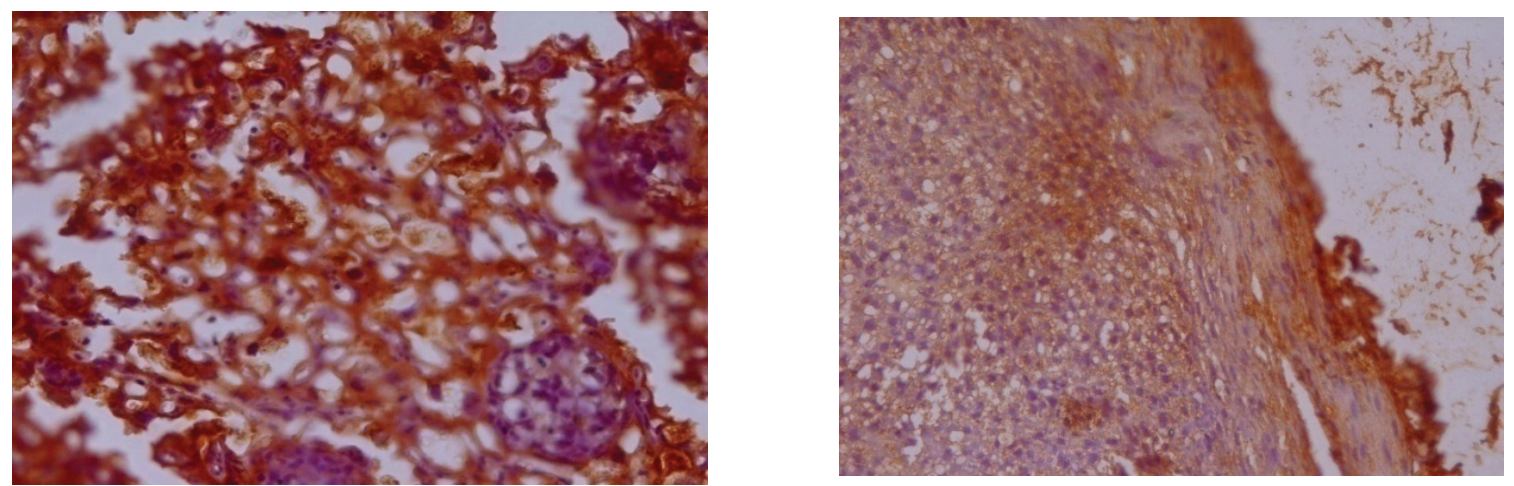

Gambar 2 Ekspresi Hsp-70 dengan Metode Imunohistokimia. Kiri: ekspresi Hsp-70 pada kehamilan normal. Kanan: ekspresi Hsp-70 pada PJT. Heat shock protein-70 positif/ bila tampak berwarna merah pada sitoplasma trofoblas dengan mempergunakan substrat AEC

Kadar HLA-G plasma pada wanita hamil juga diteliti Steinborn dkk., ${ }^{1}$ hasilnya diketahui bahwa kadar HLA-G plasma yang menurun pada wanita hamil terutama pada trimester kedua berhubungan signifikan dengan risiko terjadi preeklamsi dan PJT, sehingga dapat digunakan sebagai prediktor untuk diagnostik prenatal.

Pada penelitian didapatkan ekspresi HLA-G yang rendah pada kelompok PJT dibandingkan dengan hamil normal. Keadaan ini menunjukkan mungkin HLA-G berperan dalam toleransi imun semialogenik fetus oleh ibu. Bila ekspresi HLA-G tidak cukup maka trofoblas akan dihambat untuk menginvasi arteri spiralis karena aktivitas sel NK dan large granular lymphocytes (LGLS) desidua untuk melisiskan trofoblas. Hambatan dari invasi trofoblas akan menyebabkan hipoksia plasenta yang dapat mengakibatkan PJT.

Heat shock protein-70 (Hsp-70) merupakan kelainan protein indusibel yang diekspresikan terus-menerus dan meningkat sebagai respons terhadap stres. ${ }^{12}$ Produk stres di desidua akan memengaruhi endotel vaskular. Pada kelompok PJT oleh karena invasi sel vili korialis ke dalam desidua terganggu, maka akan terjadi hipoksia yang akan memicu peningkatan produksi Hsp70. ${ }^{13}$ Ekspresi Hsp-70 yang berlebihan penting terhadap perlindungan sel selama stres, mungkin pada jaringan plasenta PJT mengalami stres yang berlebihan dan hal ini merupakan alasan penting untuk dapat memicu peningkatan ekspresi Hsp70 sebagai efek perlindungan pada respons sel terhadap stres.

Pada penelitian ini ekspresi Hsp-70 meningkat pada jaringan trofoblas janin yang mengalami PJT dibandingkan dengan janin normal. Hasil penelitian ini sama seperti yang dilakukan oleh Barut dkk. ${ }^{6}$ yang membandingkan ekspresi Hsp70 pada 45 kasus PJT dan 45 kasus preeklamsi dibandingkan dengan 45 kasus hamil normal. Dari penelitian tersebut didapatkan hasil Hsp-70 yang meningkat pada sinsitiotrofoblas, sitotrofoblas, dan ekstravilus trofoblas pada sel plasenta PJT dan preeklamsi $(p<0,01)$ dibandingkan dengan kehamilan yang normal. Stres oksidatif mungkin memegang peran yang penting pada patogenesis kehamilan dengan PJT dan preeklamsi.

Sebagai simpulan, pada PJT ekspresi HLA-G lebih rendah dan ekspresi Hsp-70 lebih tinggi bila dibandingkan dengan kehamilan yang normal. Sebagai saran, untuk dapat memprediksi PJT, perlu dilakukan pemeriksaan kadar HLA-G dan Hsp-70 serum pada awal trimester kehamilan, sehingga tidak diperlukan tindakan invasif.

\section{Daftar Pustaka}

1. Steinborn A, Varkonyi T, Scharf A, Bahlmann F, Klee A, Sohn C. Early detection of decreased soluble HLA-G levels in the maternal circulation predicts the occurrence of preeclampsia and intrauterine growth retardation during further course of pregnancy. Am J Reprod Immunol. 2007;57(4):277-86.

2. Obgin RSUD Dr. Moewardi Surakarta. Data Obstetri. 2008.

3. Mor G, penyunting. Imunology of pregnancy. New York: Springer; 2006.

4. Weiss G, Goldsmith LT, Taylor RN, Bellet $\mathrm{D}$, Taylor HS. Inflammation in reproductive disorders. Reprod Sci. 2009;16(2):216-29.

5. Li W, Zhong X, Zhang L, Wang T, Xu R. Increased expression of heat shock protein 70 and oxidative injury in the liver of intrauterine growth retardation piglets. Advances in Biomedical Engineering. 2011;1-2:211-4. 
6. Barut F, Barut A, Dogan Gun B, Kandemir NO, Aktunc E, Harma MI, dkk. Expression of heat shock protein 70 and endothelial nitric oxide synthase in placental tissue of preeclamptic and intrauterine growthrestricted pregnancies. Pathol Res Pract. 2010;206(9):651-6.

7. Liu Y, Li N, You L, Liu X, Li H, Wang $\mathrm{X}$. HSP70 is associated with endothelial activation in placental vascular diseases. Mol Med. 2008;14(9-10):561-6.

8. Murti B. Desain dan ukuran sampel untuk penelitian kuantitatif dan kualitatif di orang kesehatan. Edisi ke-2. Jogjakarta: Gajah Mada University Press; 2010.

9. Hviid TV. HLA-G in human reproduction: aspect of genetics, function and pregnancy complications. Hum Reprod Update. 2006; 12(3):209-32.

10. Suh MJ, Moon JM, Hur SY, Kim SJ. Analysis of HLA-G expression in preeclampsia and intrauterine growth restriction. Korean J Obstet Gynecol. 2007;50(3):439-48.

11. Fan SS, Zhang JP, Shao JY, Tan JP, Liu YK, Wang YH. Placental expression of human histocompatibility antigen-G mRNA in idiopathic fetal growth restriction and its relationship with pathological changes of placenta. Zhonghua $\mathrm{Fu}$ Chan $\mathrm{Ke} \mathrm{Za}$ Zhi. 2005;40(4):249-52.

12. Padmini E, Sowmya S, Phil M. Atherosis: a major event in the pathophysiology of preeclampsia. Biomedicine. 2005;25(3-4): 6-12.

13. Fukushima A, Kawahara H, Isurugi C, Syoji T, Oyama R, Sugiyama T, dkk. Changes in serum levels of heat shock protein 70 in preterm delivery and pre-eclampsia. J Obstet Gynaecol Res. 2005;31(1):72-7. 